International Journal of Physical Sciences and Engineering
Available online at www.sciencescholar.us
Vol. 6 No. 1, April 2022, pages: 27-38
e-ISSN : 2550-6943, p-ISSN : 2550-6951
https://doi.org/10.53730/ijpse.v6n1.3147

\title{
Evolution of the Concept of Sustainable Development and its Applicability in Ecuador
}

\author{
(1) cosshank \\ María Giuseppina Vanga Arvelo a, Antonio Vázquez Pérez b, María Lourdes Piñero Martín c, Edwin \\ Roger Esteban Rivera ${ }^{d}$
}

Manuscript submitted: 27 November 2021, Manuscript revised: 18 December 2021, Accepted for publication: 09 January 2022

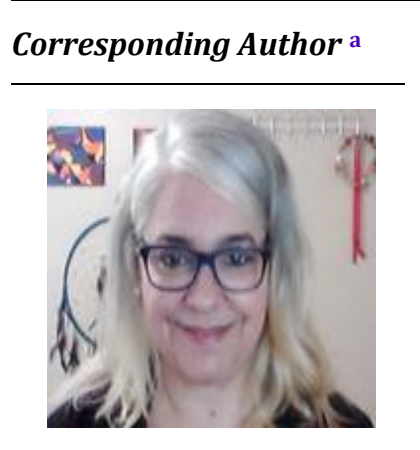

Keywords

sustainable development;

life model;

sustainability models;

sustainability paradigm;

sustainability Ecuador;

\begin{abstract}
Sustainable development has become one of the most important issues related to the quality of life and the future of humanity and, although it is a term associated with the environmental area, it is closely linked to the growth of humanity evolving into more conscious beings. The main objective of this article is to review how this concept has evolved and how it is linked to the processes and uses of clean energy in favor of making use of it as a life model. The results indicate that there has been progressing in terms of government efforts, although there is still a long way to go. It is concluded the most appropriate sustainability model to follow is the one that links the social, economic, and cultural dimensions, without neglecting the participation of the actors and taking the environment as an actor that exercises and has established its rights established in the Constitution of Ecuador.
\end{abstract}

International Journal of Physical Sciences and Engineering (C) 2022. This is an open access article under the CC BY-NC-ND license (https://creativecommons.org/licenses/by-nc-nd/4.0/).

\section{Contents}

Abstract.

1 Introduction...

2 Materials and Methods.

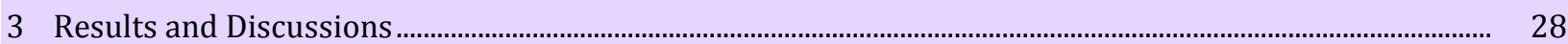

4 Conclusion

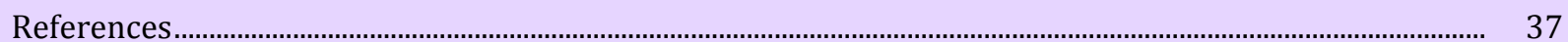

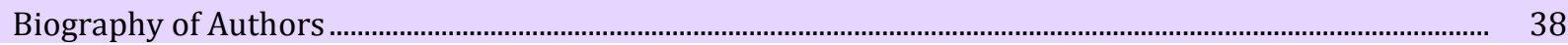

\footnotetext{
a Universidad Técnica de Manabí, Portoviejo, Ecuador

b Universidad de Alicante, Alicante, España

c Universidad Pedagógica Experimental Libertador, Barquisimeto, Venezuela

d Universidad Nacional Hermilio Valdizán, Huánuco, Perú
} 


\section{Introduction}

Human life develops in a continuous present that, unfortunately, returns to the most intelligent beings on the planet, beings with a single goal such as satisfying themselves in that present, without looking at the changes that have been caused, and without thinking about the consequences that come from its presence in the future. This inability to see beyond the values, rights, duties, but especially, disarticulates the human from his humanity by becoming the most lethal enemy of the earth itself, land that is home to humanity, land capable of sustaining itself without humanity, but not the other way around (Du Plessis \& Brandon, 2015; Janeiro \& Patel, 2015).

Reflecting on human performance at least seems like a ray of light in a tunnel that seems to have no end. This reflection is individual and particular, it is intimate and philosophical, it is special for each individual if it exists. Those who can even look back and into the future and who can even think about how their manifest performance modifies their environment will be the hope of the world. "An incompatibility has arisen in the modus vivendi of the human and the natural, leading to an imbalance between the human being, the habitat, and nature" (Giuseppina Vanga et al., 2021), and that must be remedied. The main objective of the research on which this article is based is to review the change that the concept of sustainable development has undergone since its first mention and how this concept is linked to the processes and uses of clean energy based on making use of him as a life model.

\section{Materials and Methods}

This is basic research, which according to Esteban Nieto (2018), supports applied research and is essential for the development of science. According to its scope, it is descriptive since it describes the phenomenon, situations, contexts, and events (Hernández-Sampieri \& Torres, 2018), associated with sustainable development. A bibliographic review was carried out during December 2021 in databases such as Scopus, Latindex, Scielo, among others.

\section{Results and Discussions}

As a result of the analysis carried out on the different bibliographic sources consulted and their discussion is presented below the origin of the term sustainable development, the new paradigm of sustainability, sustainability models, sustainable development as a life model, and, finally, sustainability in Ecuador.

\section{Origins}

The word has Latin roots and means the quality of standing up for yourself. The Royal Spanish Academy defines sustainability as a feminine name that indicates the quality of sustainability and sustainable as an adjective that can be sustained, maintained for a long time without depleting resources or causing serious damage to the environment (RAE, 2021). According to Henández-Mendible (2014), the concept of sustainable development is constantly evolving, the product of "... a maceration process that has allowed its progressive formulation by international organizations, to then be filtered in a process of decantation and assimilation in the order internal countries" (p. 7). Table 1 shows part of this transformation.

Table 1

Evolution of the concept of sustainability

\begin{tabular}{lll}
\hline Year & \multicolumn{1}{c}{ Instrument } & \multicolumn{1}{c}{ Concept } \\
\hline \multirow{2}{*}{1972} & $\begin{array}{l}\text { Stockholm } \\
\text { Declaration: United }\end{array}$ & $\begin{array}{l}\text { Principles 1, 2, and 8: Man has the fundamental right to freedom, } \\
\text { equality, and the enjoyment of adequate living conditions, in an }\end{array}$ \\
\hline
\end{tabular}


Nations Conference

on the Human

Environment (26

principles and a plan

of action for the future)

Global Strategy for Conservation: International Union

1980 for the Conservation of Nature and Natural Resources (Section Towards Sustained Development)

United Nations General Assembly:

1982 World Charter for Nature (General Principles and Functions)

Organization of the United Nations: Our Common Future Report or Brundtland Commission Report (Definition of Sustainable Development)

Earth Summit (United Nations): Rio de Janeiro Declaration on Environment and Development $(27$ principles)

2000 United Nations: Millennium environment of such quality as to enable him to lead a dignified life and enjoy well-being and has a solemn obligation to protect and improve the environment for present and future generations. The Earth's natural resources must be preserved for the benefit of present and future generations through careful planning or management, as appropriate. Economic and social development is indispensable to ensure a favorable living and working environment for man and to create on Earth the conditions necessary to improve the quality of life (United Nations, 1973).

It highlights the main causes of habitat destruction and poverty, and social inequality, among others. It calls for a new international development strategy with a more dynamic economy considering the impact of poverty, points out sustainability in ecological terms. Achieving equitable and sustained development requires not only the implementation of established measures but also the implementation of a global strategy for conservation (IUCN, 1980).

Conservation principles shall apply to all parts of the earth's surface. Ecosystems and organisms, as well as terrestrial, marine and atmospheric resources that are used by man, shall be managed in such a way as to achieve, and maintain their optimal and continuous productivity without jeopardizing the integrity of the other ecosystems and species with which they coexist. Decision-making processes will recognize the needs of all cannot be met unless the proper functioning of natural systems is ensured. In the planning and implementation of social and economic development activities, due account shall be taken of the fact that nature conservation is an integral part of such activities. In formulating long-term plans for economic development, population growth and improved living standards, due account shall be taken of the long-term capacity of natural systems to ensure the settlement and survival of the populations concerned, recognizing this capacity can be enhanced through science and technology. Natural resources will not be wasted. Activities that may have consequences on nature will be monitored (United Nations, 2019).

One that responds to the needs of the present in an egalitarian way, but without compromising the possibilities of survival and prosperity of future generations (United Nations, 1987).

Human beings are at the heart of sustainable development concerns. They have the right to a healthy and productive life in harmony with nature. States should enact effective environmental legislation. Environmental standards, management objectives, and priorities should reflect the environmental and development context to which it applies. The evolution begins in the construction of a concept of integral sustainable development, that is, one that includes the economic, social, environmental, and technological fields, to guarantee the life and dignity of people (United Nations, 1992).

It assumes a resolute commitment to the dignity of the human person. We are resolved through decisions on goals, timelines, and partnerships

Arvelo, M. G. V., Pérez, A. V., Martín, M. L. P., \& Rivera, E. R. E. (2022). Evolution of the concept of sustainable development and its applicability in Ecuador. International Journal of Physical Sciences and Engineering, 6(1), $27-$ 
Declaration

(Preparation of the

World Summit on

Sustainable

Development)

United Nations

Conference on

Sustainable

2012 Development: Rio+20, the future we want (Declarations of good intention) to rapidly increase access to basic requirements such as clean water, sanitation, adequate housing, energy, public health, food security, and biodiversity protection. At the same time, we will work together to assist each other in accessing financial resources, benefiting from opening markets, ensuring capacity building, using modern technology to generate development, and ensuring technology transfer, human resource development, and training to banish underdevelopment forever (Henández-Mendible, 2014).

The commitment to sustainable development is ratified, the steps to achieve it are exposed, such as: the eradication of poverty; mainstreaming sustainable development at all levels; and sustained, inclusive and equitable growth, creating greater opportunities for all, reducing inequalities, improving basic living standards, promoting equitable social development and inclusion, and promoting integrated and sustainable management of natural resources and ecosystems that support them. The commitments made in the Millennium Development Goals are reaffirmed. It reiterates the human person as the central axis to achieve sustainable development, reaffirms the importance of the Universal Declaration of Human Rights, that the participation of the state is essential, and the commitment to strengthen international cooperation for developing countries (United Nations, 2012).

Source: own elaboration from other authors.

\section{The new sustainability paradigm}

Environmental problems are proof of the existence of natural limits, which in turn has driven sustainability as the conciliatory paradigm between what the environment offers in natural resources and the production of goods and services; it is about achieving a harmony between the natural world and the human world that desires well-being (Perez Rincon, 2010).

According to Rodríguez (2016), the concept of sustainability has long been seen from the environmental perspective, however, in the changing era in which it is, the concept permeates other dimensions. Various disciplines try to glimpse the responsibility of consumption and how it can be done more responsibly, integrally seeing the concept. Previously, the culture of artisanal production generated few problems to natural resources, but, the success in improving the quality of life has brought as a consequence a greater offer of products making it seem to the human to have control over nature.

The author comments that the great debt of these industrialization processes falls on a lack of commitment to natural resources and their responsible use, with resources being unable to respond to excessive demands. This problem was seen as a problem of the environment or ecology, and it is thus in terms of sustainability and territory that over time, the territories needed to have a holistic vision of sustainability including the social and cultural perspective, biophysics, politics, and the economy (Curran, 2013; Geissdoerfer et al., 2017).

The complex problem of sustainability began to be seen as an inclusive problem addressed from the systemic complexity intervening human beings, institutions, and the productive and economic apparatus. This complex issue is increasingly attracting the attention of researchers, producers, and the State. The problem is not integrating many sciences, but rather in internalizing how from responsible consumption, commensurate policies, and environmentally friendly products tangible solutions are given without affecting resources in the future (id.).

Current and future actions must be seen in the light of the sustainability paradigm at all levels, from local to international. Sustainable development requires humanity to integrate and to balance what you have and what you want, between satisfaction and ecological integrity, between individualism and the vision of the world as an integral being, between selfishness and the sense of belonging to the earth (Hall et al., 2010; Bhattacharyya, 2012). 
Sustainability models

Models based on sustainable development arise from satisfaction in the present without compromising the future. Sustainable development in the light of organizations should be seen as a new way of analyzing how their performance is, based on four perspectives such as economic, social, institutional, and environmental. The relationships between these dimensions have been identified, such as institutional education, which can encompass the social and environmental part, and eco-efficiency for the environmental and economic (Carro Suárez et al., 2017).

It is noteworthy that every model must be built based on culture, in this case, a culture of sustainability in all aspects, from the family to institutions and the State. Sustainability must be a cross-cutting concept not only in education but in human life itself. Sustainability must be an inherent part of the Being and therefore must be part of its values and traditions, of the daily and sporadic, of the superfluous and the complex. The most recognized models of sustainability so far are four: Brundtland Model, UK Government Statistical Service Model, Achkar Tetrahedron Model, and the Barber-Zapata Model.

The Brundtland Model is taken as a model, is based on the 1987 Report of the UN World Commission on Environment and Development led by Dr. Gro Harlem Brundtland who, from an analysis of the world situation at that time, determined the path of society destroys the environment and leaves more and more people vulnerable and in poverty (Dincer, 2000; Moran et al., 2008; Nehru, 2016). The model aimed to find ways to reverse the damage caused to the planet, so we worked with public hearings for three years, and with the data collected a document was made where it was established that environmental protection no longer responded to a local or national issue, but global, so everyone had to work to reverse environmental degradation (DMF, 2017). The other three models, like the one mentioned, also cover the dimensions: social, economic, and environmental. Table 2 shows a comparison of the four models.

Table 2

Sustainability models

\begin{tabular}{|c|c|c|c|c|}
\hline \multirow{2}{*}{ Model } & \multirow{2}{*}{ Year } & \multicolumn{3}{|c|}{ Dimension } \\
\hline & & Social & Economic & Environmental \\
\hline $\begin{array}{l}\text { Brundtland } \\
\text { Model }\end{array}$ & 1987 & $\begin{array}{l}\text { Highlights health, } \\
\text { education, equity, } \\
\text { housing, and security. }\end{array}$ & $\begin{array}{l}\text { Economic development } \\
\text { is the main factor. }\end{array}$ & $\begin{array}{l}\text { Care of air, soils, and } \\
\text { water. }\end{array}$ \\
\hline $\begin{array}{l}\text { Model UK } \\
\text { government } \\
\text { statistical } \\
\text { service (GSS, } \\
\text { 2004)) }\end{array}$ & 2004 & $\begin{array}{l}\text { It considers health, the } \\
\text { promotion of skills, } \\
\text { motivation, knowledge, } \\
\text { and spirit as a priority. }\end{array}$ & $\begin{array}{l}\text { Attention to buildings } \\
\text { and machinery stands } \\
\text { out. }\end{array}$ & $\begin{array}{l}\text { Prioritizes the care and } \\
\text { good management of } \\
\text { minerals, forests, flora, } \\
\text { fauna, water, air, and } \\
\text { soils. }\end{array}$ \\
\hline $\begin{array}{l}\text { Achkar } \\
\text { tetrahedron } \\
\text { model }\end{array}$ & 2005 & $\begin{array}{l}\text { Good relations between } \\
\text { social classes are the } \\
\text { main factor. }\end{array}$ & $\begin{array}{l}\text { Consider property } \\
\text { relations and finance } \\
\text { circuit. }\end{array}$ & $\begin{array}{l}\text { It highlights the } \\
\text { relationships of the use } \\
\text { and management of the } \\
\text { goods of nature for the } \\
\text { benefit of humanity. }\end{array}$ \\
\hline $\begin{array}{l}\text { Barber-Zapata } \\
\text { Model }\end{array}$ & 2009 & \multicolumn{3}{|c|}{$\begin{array}{l}\text { Sustainable development is achieved by intertwining the three dimensions, if } \\
\text { any is omitted it will be another development. }\end{array}$} \\
\hline
\end{tabular}

Source: prepared from Carro Suárez et al. (2017)

The Barber-Zapata Model combines the three dimensions in such a way that, only when all three are properly addressed, does sustainable development occur. If one of the dimensions failed, there would be development, but of a different kind; thus, if the social and environmental dimension is considered, but the economic one is neglected, it would be a bearable development. If the social and economic dimension is taken into account, neglecting the environmental dimension, equitable development would be achieved; if the environmental and economic part is taken into account, there would be a viable development, but in none of the cases raised would it be sustainable (see Figure 1).

Arvelo, M. G. V., Pérez, A. V., Martín, M. L. P., \& Rivera, E. R. E. (2022). Evolution of the concept of sustainable development and its applicability in Ecuador. International Journal of Physical Sciences and Engineering, 6(1), $27-$ 


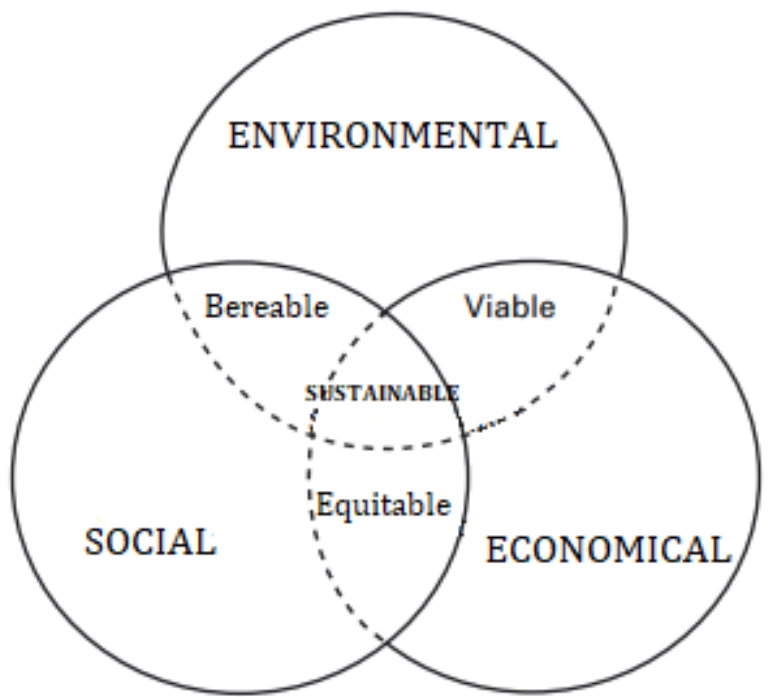

Figure 1. Dimensions of sustainable development Source: Barber \& Zapata (2009)

\section{Sustainable development as a life model}

The models presented when working by dimensions indicate the elements that make up the complex variable that is sustainable development. It would be interesting to include in these structural blocks the actors since the manifestation of sustainability in development depends largely on them. The maintenance of the social and economic dimensions is then proposed, adding the cultural one based on the fact that, without culture, there is no change and without change, there will be no return. On the other hand, it is proposed the ambient dimension becomes at the height of the actors, no longer counted as dimensions but as protagonists (see Figure 2). It should be noted that, in Ecuador, in the Constitution of the Republic of 2008, the exercise of rights is given both for individuals, communities, peoples, nationalities, and groups as well as for nature (National Assembly, 2008).

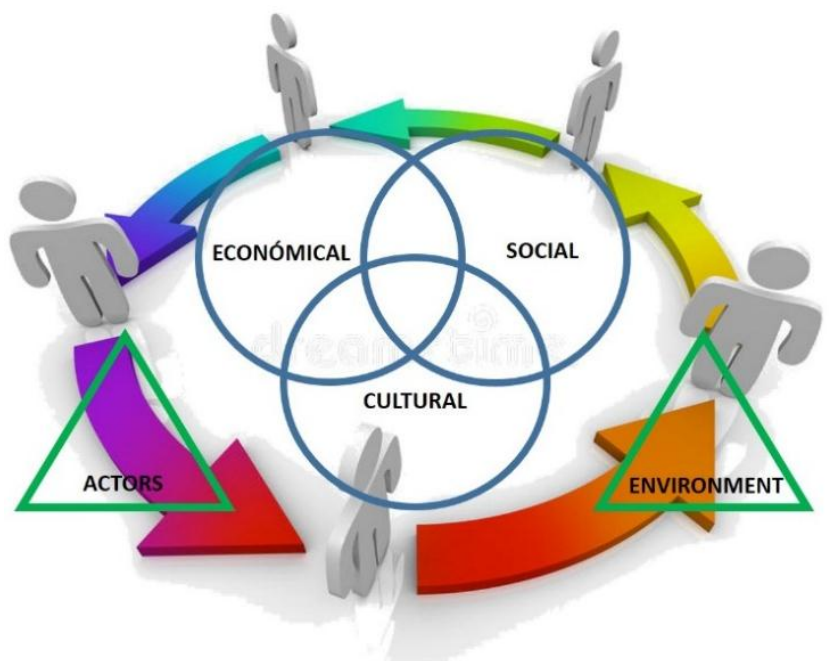

Figure 2. New model of sustainable development Source: own elaboration.

The adoption of a life model based on sustainability is not an easy task, especially since it is from altruism that this model must be erected. From the point of view of those involved such as the actors and the environment, 
the human being must reflect on the axiom that indicates humans need nature, nature doesn't need humans. And it is precisely from these protagonists that the weight of the bases must fall, considering that nature heals itself, regenerates, even though there is an inherent change that necessarily accompanies the laws that govern the physics of the planet such as the change of the poles, to name a few. These changes that will happen with humans or without humans have their time in space and you could think that whatever is done, will happen, however, what the actors do is accelerate it in such a way that, maybe that incidence changes in some respects, unknown yet, that planetary physics. There is no right to break through the natural course of events the planet has had in its evolutionary cycle. It is, therefore, necessary that the most important dimension, the cultural one, come into action (Shade, 2015; Kerr, 2005; Gamez et al., 2016).

If culture shapes the identity of peoples, that identity must be manifested through the practice of sustainable values, environmentally speaking. Literature tells us that culture "are values that keep cultural roots alive and, at the same time, produce genuine democratic policies that are based on enigmatic commitments to open, participatory and equitable cooperation, on political discourse and decision-making" (Sustainable Development, 2021). However, culture in this space does not even refer to the attempt to preserve future generations but, to do so, because that is how it should be. Care must be intrinsic, it must arise, without forcing, without makeup; it does not save on energy expenditure by reducing the electricity bill, it is saved by reducing the impact that the production of that energy generates and by reducing the footprint of those effects.

The sustainable culture must therefore be in everything, immersed in the upbringing of the little ones where adults with their example teach them, at all stages of education, as a flag of organizations, in all fields. Sri Sathya Sai, a teacher from India said that an integral education "... combines secular and spiritual education" (2008). An integral education based on values aims to have intellectual training, but, in addition, "... the constant light of an awakened intuition. In other words, must have an integral education, which combines the brilliance of reason with the calm and depth of moral and spiritual education (ibid., p. 22).

Faced with this, parents and teachers have a great responsibility and have the duty to influence the morale of future generations. For Albornoz (1996), morality encompasses "... the set of value judgments, ideals, virtues and institutions through which man tends to realize the values of the good". Therefore, the moral domain is the "... issues of welfare, justice, rights, and matters that are intrinsically correct and that are not alterable by consensus. Such matters are fixed and unalterable" (Kurtines \& Gewirtz, 1995).

Ethics, values, morality, and spirituality (seen not from a specific doctrine or a philosophical school or ideology, but rather from a spiritual condition of cultivation of the immaterial), must therefore be the pillars of a transversal integral education in all areas, which forges character, and, therefore, culture. Bailey (2007), indicated the education of the new age does not mean acquiring attitudes, skills, and knowledge, but learning to expand consciousness and know-how to reconcile humanity and the divine elements that constitute man.

\section{Sustainability in Ecuador}

Ecuador in 2005, signed a Basic Cooperation Agreement between the United Nations Development Program (UNDP) and the Ecuadorian State to develop programmers and projects in various areas of development, with the National Government being responsible for the activities and their implementation. UNDP supports the efforts of countries to achieve the Sustainable Development Goals (SDGs) through monitoring, policy and technical advice, and detailed analysis and reporting on progress towards these goals (UNDP Ecuador, 2021). The UNDP Strategic Plan proposes six flagship solutions for the achievement of the SDGs as integrated responses to development that cover the areas: poverty, governance, resilience, gender, environment (naturebased development solutions), and energy (clean and affordable).

In March 2021, UNDP delivered the Human Development Report 2020, where its authors tell world leaders that strong action must be taken to lessen the pressure on the natural world and the environment because, if it does not, human progress will stop. They indicate we are facing a new geological era that is the Anthropocene or the era of human beings (era where human beings cause a great impact on the earth); indicates it is time for all the countries to redesign the trajectory of its progress, eliminating the imbalance of power and opportunities that prevent real change from taking place (UNDP Ecuador, 2021).

In the presentation of the report, the Minister of Foreign Affairs and Human Mobility of Ecuador, Luis Gallegos Chiriboga, points out that environmental conservation and protection, as well as the sustainable use

Arvelo, M. G. V., Pérez, A. V., Martín, M. L. P., \& Rivera, E. R. E. (2022). Evolution of the concept of sustainable development and its applicability in Ecuador. International Journal of Physical Sciences and Engineering, 6(1), 27. 
of biological diversity, have been integrated into the norms and public policy. More than $10 \%$ of marine and coastal areas were preserved in 2020. A necessary change in social norms related to the interaction between human beings and nature and how resources are managed was highlighted. Included in the Human Development Index (HDI), which measures the standard of living, education, and health, elements such as material footprint and carbon dioxide emissions. Ecuador obtains 2019 a 0.759 in this index (high human development).

Human development is the process that a society goes through to improve the living conditions of its citizens (Montagud, 2021). However, this index is only an indicator and as such, may not reflect reality by showing a development, but in the long term; the three dimensions measured by the index are not sufficient to reflect it. This is an attempt to say that, regardless of the cataloging that a country has with indices such as the $\mathrm{HDI}$, it should be aimed at education and the culture of sustainability. Although Ecuador was also recognized by the United Nations (UN) as a model of sustainable development in the reduction of inequality and the eradication of poverty (at the 11th Annual Meeting of the UN) through the Good Living model, it is seen how still most of the efforts and investments are not enough (America Economy, 2014).

As for electrical energy, the latest Master Plan presented by the Ministry of Energy and Non-Renewable Natural Resources and still in force, indicates they are heading to guarantee the electricity supply by prioritizing the participation of renewable energies, especially hydroelectric. "Renewable sources in the country accounted for $72.58 \%$; of which $97.43 \%$ corresponds to hydropower, $1.8 \%$ Biomass, $0.18 \%$ photovoltaic, $0.38 \%$ wind, and $0.21 \%$ Biogas" (Briones, 2019). In Table 3 you can see other data of interest.

Table 3

Data on electric power in Ecuador to 2018

\begin{tabular}{|c|c|c|c|}
\hline & & Renewable Sources & Non-Renewable Sources \\
\hline Installed power & $8.826,89 \mathrm{MW}$ & $59,84 \%$ & $40,16 \%$ \\
\hline Energy production & $29.243 \mathrm{GWh}$ & $21.224,31$ GWh $(72,58 \%)$ & $8.019,28$ GWh $(27,42 \%)$ \\
\hline $\begin{array}{l}\text { Production of the National } \\
\text { Interconnected System } \\
\text { (NIS) by type of energy }\end{array}$ & & 21.198,02 GWh (83,54 \%) & 4.177,89 GWh $(16,46 \%)$ \\
\hline Generation Plant Capacity & & $\begin{array}{l}5.231,72 \text { MW }(64 \%) \\
\text { 72,58 \%: } \\
\text {. hydroelectric } 20,661.59\end{array}$ & 2.950,85 MW (36 \%) \\
\hline $\begin{array}{l}\text { Contribution of Centrals in } \\
\text { the NIS }\end{array}$ & & $\begin{array}{l}\text { GWh } \\
\text { thermal } 4,177.90 \mathrm{GWh} \\
\text {. photovoltaic } 34.77 \mathrm{GWh} \\
\text {. biogas } 45.52 \mathrm{GWh} \\
\text {. wind power } 73.70 \mathrm{GWh}\end{array}$ & $27,42 \%$ \\
\hline
\end{tabular}

Source: own elaboration from Briones (2019)

It is important to note, how the effective power capacity in the National Interconnected System has evolved from 2008 to 2018, as shown in Figure 3. 


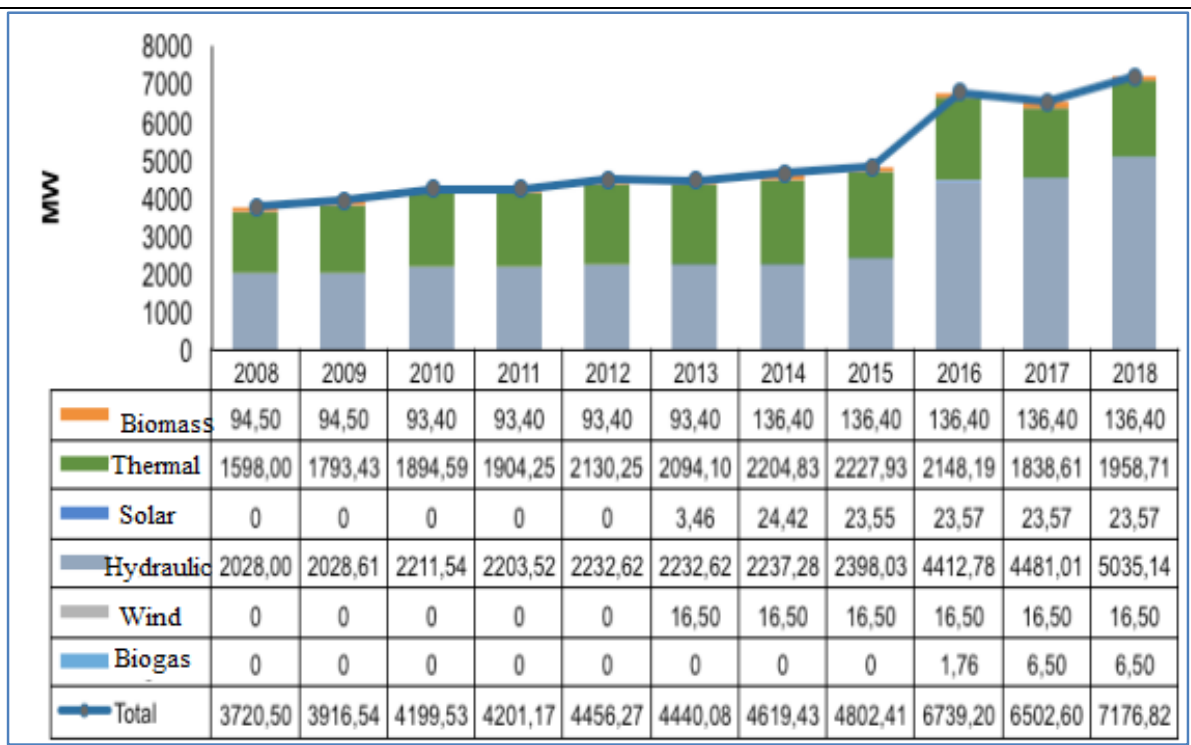

Figure 3. Evolution of the effective power capacity in the NIS period 2008-2018

Source: Briones (2019)

As for the capital investment of the Transmission Expansion Plan 2018-2027, it analyzes those infrastructure requirements "... necessary at the transmission level for the evacuation of all the generation of the NonConventional Renewable Energy blocks and the entry of the Combined Cycle thermoelectric project by 2022" (Briones, 2019). The plan contemplates the following investment, shown in Figure 4.

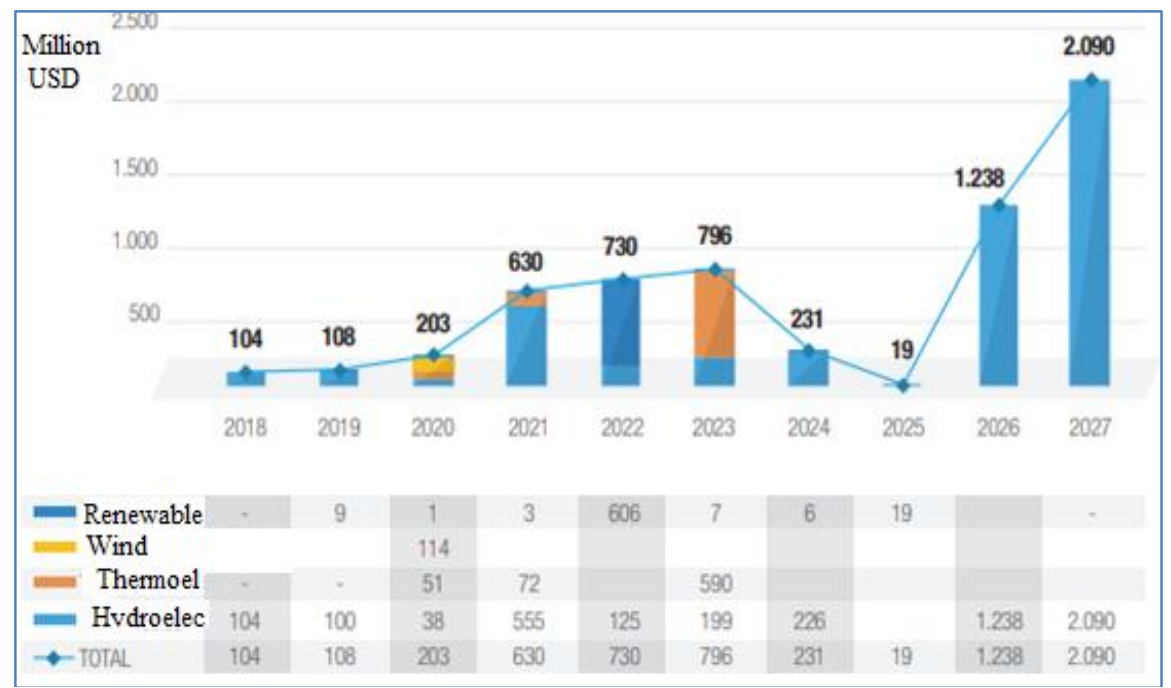

Figure 4. Capital investment in generation by type of technology

Source: Briones (2019)

However, even though it is already on track to consciously work with renewable energies, if we look at the forecast of annual demand for electricity for the year 2027 (see Figure 5), it would be important to ask whether the required generation projects will be enough? Will the vision of this plan to turn Ecuador into an exporting country be possible when there are still unsupplied areas?

Arvelo, M. G. V., Pérez, A. V., Martín, M. L. P., \& Rivera, E. R. E. (2022). Evolution of the concept of sustainable development and its applicability in Ecuador. International Journal of Physical Sciences and Engineering, 6(1), $27-$ 


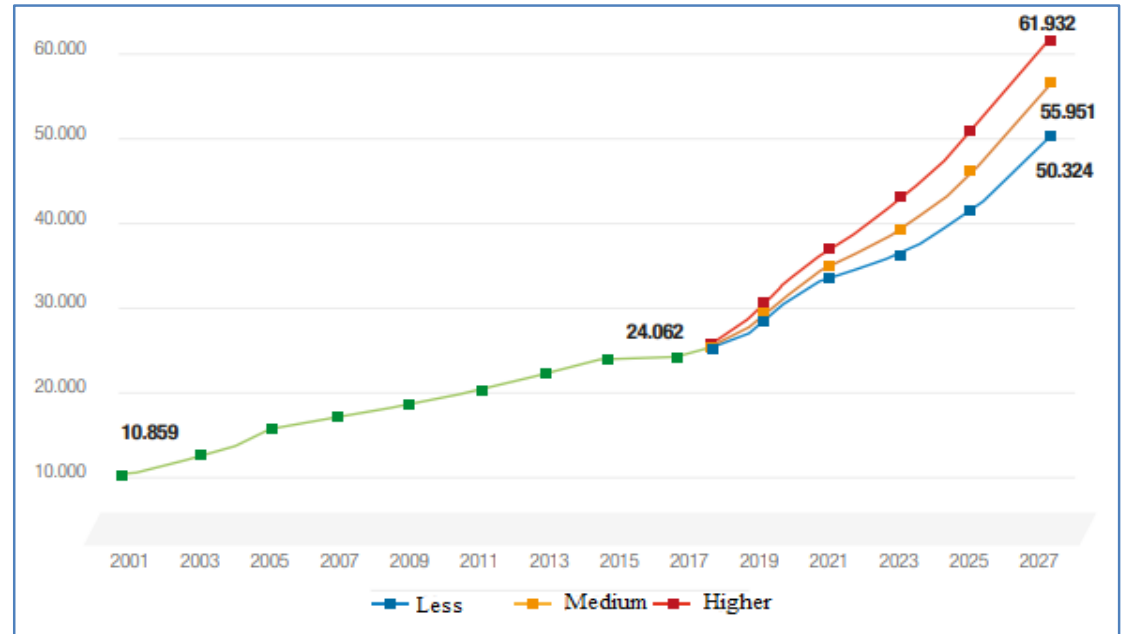

Figure 5. Forecast of the annual demand for electrical energy (Gwh) in generation terminals of the NIS Source: Briones (2019)

Despite indicating that, for the development of the Transmission Expansion Plan 2018 - 2027, an investment of 1,793.09 million dollars is required, being indispensable the timely disposition of resources. The answer to the questions posed above is in the hands of time, the State, the organizations involved, and citizen conscience in general. We must pay tribute, however, to the efforts made in 2020, where the provincial Decentralized Autonomous Governments (DAG) executed the following actions:

1) allocated in millions of dollars:

a) more than 7 to the execution of environmental management projects,

b) 1.9 for 43 climate change projects,

c) 25 in 156 development and development projects,

2) 12 provincial DAG (50\%) issued regulations for the defense of natural resources and,

3) $71 \%$ of the provincial DAG had an irrigation and drainage plan based on a local management model that contributes to the sustainable use and exploitation of water for agriculture (INEC, 2021).

\section{Conclusion}

Sustainable development is necessary for everyone and at the same time an individual internal work that will affect culture being the sustainable resource of the environment, its concept is still evolving, and this will depend on human action. The new paradigm of sustainability implies a holistic vision that includes the social, cultural, biophysical, political, and economic perspective; not enough just to integrate many sciences in the conception of sustainable development, but rather to provide tangible solutions without affecting the resources of the future through responsible consumption, appropriate policies and environmentally friendly products.

The most appropriate model of sustainable development proposed so far is one in which the social, economic, and environmental dimensions are integrated; nevertheless, sustainable development as a life model includes the integration of three dimensions such as social, economic, and cultural contemplating transversal axes such as actors (which includes individuals and organizations) and the environment. Culture shapes the identity of peoples and that identity must be manifested through the practice of sustainable values based on education. In Ecuador, efforts have been made to carry out actions where the use of clean energy has been integrated, prioritizing resources; however, it is necessary to continue reflecting on human performance and its impact on the environment and especially, it must continue to educate to achieve a sustainable collective conscience regarding the environment. 


\section{References}

Albornoz, J. (1996). Ethics for young people. Venezuela: Vadell Hermanos Editores.

Bailey, A. (2007). Education in the new age.

Barber, C.M., \& Zapata, M. (2009). Sustainability or Sustainability. III Symposium on Research Applied to Business (Memoirs). Mexico, Anahuac University Mexico South.

Bhattacharyya, S. C. (2012). Energy access programmes and sustainable development: A critical review and analysis. Energy for sustainable development, 16(3), 260-271. https://doi.org/10.1016/j.esd.2012.05.002

Briones, J. (2019). Electricity Master Plan. Ecuador: Ministry of Energy and Non-Renewable Natural Resources.

Carro Suárez, J., Reyes Guerra, B., Rosano Ortega, G., Garnica González, J., \& Pérez Armendáriz, B. (2017). Sustainable development model for the ceramic tile industry. International Journal of Environmental Pollution , 33 (1), 131-139.

Curran, M. A. (2013). Life cycle assessment: a review of the methodology and its application to sustainability. Current Opinion in Chemical Engineering,2(3), 273-277. https://doi.org/10.1016/j.coche.2013.02.002

Dincer, I. (2000). Renewable energy and sustainable development: a crucial review. Renewable and sustainable energy reviews, 4(2), 157-175. https://doi.org/10.1016/S1364-0321(99)00011-8

Du Plessis, C., \& Brandon, P. (2015). An ecological worldview as basis for a regenerative sustainability paradigm for the built environment. Journal of Cleaner Production, 109, 53-61. https://doi.org/10.1016/j.jclepro.2014.09.098

Esteban Nieto, N. (2018). Types of research.

Gamez, M. R., Perez, A. V., Arauz, W. M. S., \& Jurado, W. C. C. (2016). Sustainable transformation of energy matrix. International Research Journal of Engineering, IT \& Scientific Research, 2(9), 37-43. Retrieved from https://sloap.org/journals/index.php/irjeis/article/view/511

Geissdoerfer, M., Savaget, P., Bocken, N. M., \& Hultink, E. J. (2017). The Circular Economy-A new sustainability paradigm?. Journal of cleaner production, 143, 757-768. https://doi.org/10.1016/j.jclepro.2016.12.048

Giuseppina Vanga, M., Briones, O., Zevallos, I., \& Delgado, D. (2021). Bioconstruction of single-family social housing with Guadua angustifolia Kunth cane. Novasinergia Digital Magazine , 4 (1), 53-73.

Hall, J. K., Daneke, G. A., \& Lenox, M. J. (2010). Sustainable development and entrepreneurship: Past contributions and future directions. Journal of business venturing,25(5), 439-448. https://doi.org/10.1016/j.jbusvent.2010.01.002

Henández-Mendible, V. (2014). The paradigm of sustainable development as a condition for the use and exploitation of natural resources in MERCOSUR. In C. Tablante and H. Jiménez (coords.). Oil. Blessing or Curse. 100 Years of Zumaque I. Venezuela: La Hoja del Norte.

Hernández-Sampieri, R., \& Torres, CPM (2018). Research methodology (Vol. 4). Mexico^ eD. F DF: McGraw-Hill Interamericana.

Janeiro, L., \& Patel, M. K. (2015). Choosing sustainable technologies. Implications of the underlying sustainability paradigm in the decision-making process. Journal of Cleaner Production, 105, 438-446. https://doi.org/10.1016/j.jclepro.2014.01.029

Kerr, S. A. (2005). What is small island sustainable development about?. Ocean \& Coastal Management, 48(78), 503-524. https://doi.org/10.1016/j.ocecoaman.2005.03.010

Kurtines, W., \& Gewirtz, J. (1995). Moral Development; An Introduction.

Montagud, N. (2021). Human Development Index (HDI): what it is and how it is calculated.

Moran, D. D., Wackernagel, M., Kitzes, J. A., Goldfinger, S. H., \& Boutaud, A. (2008). Measuring sustainable development-Nation by nation. Ecological economics, 64(3), 470-474. https://doi.org/10.1016/j.ecolecon.2007.08.017

Nehru, R. (2016). Corporate social responsibility \& education for sustainable development. International Research Journal of Engineering, IT \& Scientific Research,2(3), 72-81. Retrieved from https://sloap.org/journals/index.php/irjeis/article/view/490

Perez Rincon, M.A. (2010). Sustainable development: principles, applications and policy guidelines for Colombia (No. 333.715 D4).

Rodriguez, J. (2016). The new paradigm of sustainability. Colombia: Universidad Cooperativa de Colombia.

Arvelo, M. G. V., Pérez, A. V., Martín, M. L. P., \& Rivera, E. R. E. (2022). Evolution of the concept of sustainable development and its applicability in Ecuador. International Journal of Physical Sciences and Engineering, 6(1), $27-$ 
Shade, L. (2015). Sustainable development or sacrifice zone? Politics below the surface in post-neoliberal Ecuador. The Extractive Industries and Society, 2(4), 775-784. https://doi.org/10.1016/j.exis.2015.07.004

\section{Biography of Authors}

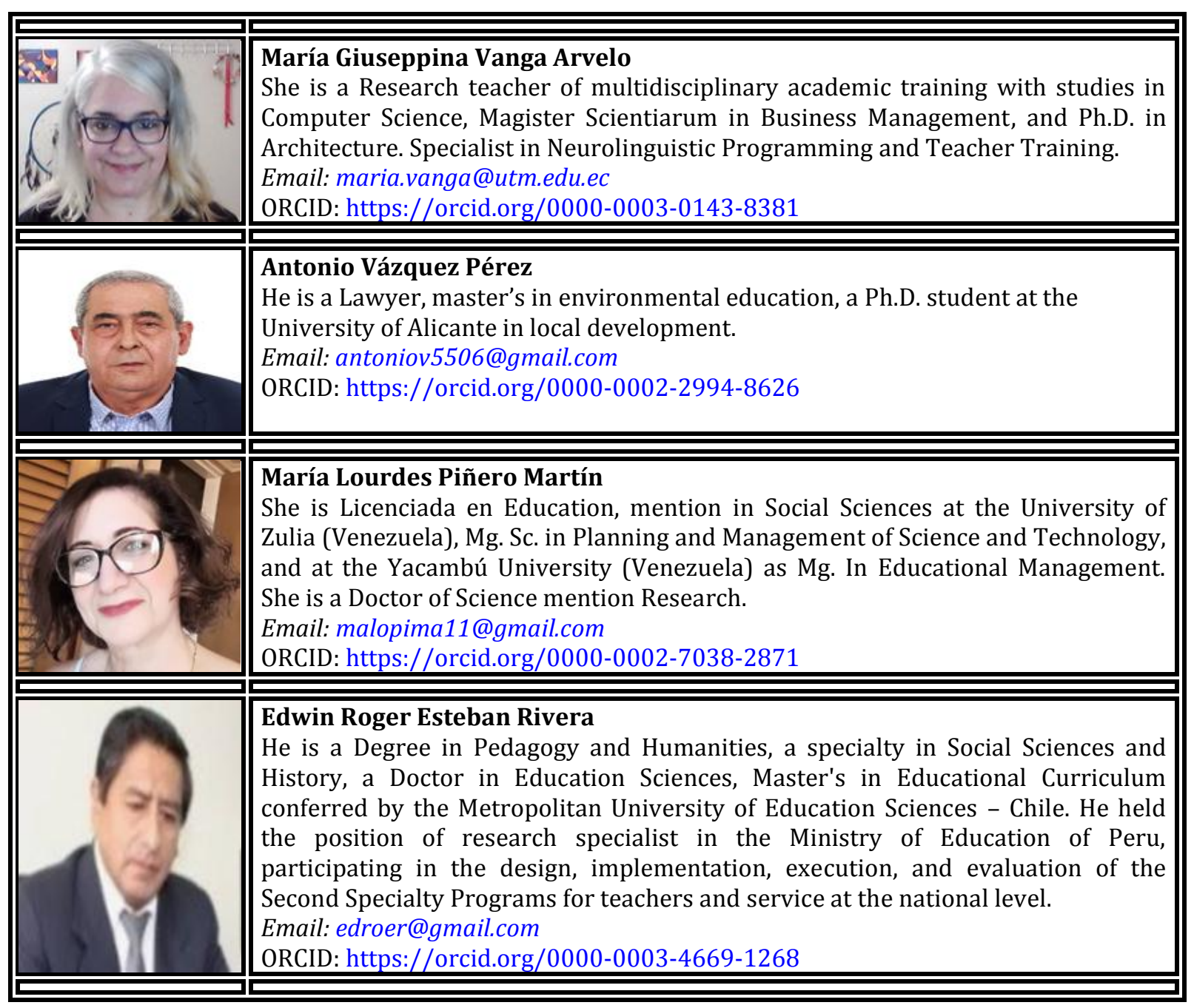

